\author{
Вељко Ж. БРБОРИЋ \\ Филолошки факултет \\ Универзитета у Београду
}

\title{
ДРУШТВЕНОИСТОРИЈСКИ АСПЕКТИ СРПСКОГ ПРАВОПИСА ИЗМЕЪУ ДВА СВЕТСКА РАТА
}

\begin{abstract}
У раду се говори о правопису нашег (српског/српскохрватског) језика између два светска рата на подручју бивших „истојезичних република”, данас самосталних држава - Србије, Хрватске, Босне и Херцеговине и Црне Горе. Заправо, реч је о прихватању Вуковог (српског) правописа и његових решења пре стварања прве Југославије и утицају друштвеноисторијских околности на правопис у периоду између два светска рата.
\end{abstract}

Кључне речи: српски правопис, „истојезичне републике”, Белићев Правопис, Боранићев Правопис, Правописно упутство, период између два светска рата.

\section{1. Увод}

После Првог светског рата, 1. децембра 1918. године, створена је прва Југославија, заузимала је територију данашње Србије, Босне и Херцеговине, Републике Северне Македоније и Црне Горе, и највећи део данашње Хрватске и Словеније, а њен службени назив је био Краљевство Срба, Хрвата и Словенаца. Тај назив је 1920. године преименован у Краљевина Срба, Хрвата и Словенаца, а званичан назив државе од 1929. до Другог светског рата и њеног нестанка био је Краљевина Југославија. У почетку је службени назив језика био српско-хрватско-словеначки. ${ }^{1}$ Ипак, званичан назив језика није одговарао реалном стању и није спорно да су и тада, ако изузмемо данашњу Словенију и Македонију, на остатку територије егзистирале касније чети-

\footnotetext{
"brboricv@fil.bg.ac.rs

${ }^{1}$ Устав Краљевине Срба, Хрвата и Словенаца из 1920. године у члану 3 каже: „Службени језик Краљевине је српско-хрватско-словеначки” (Српски устави 2004: 191). Идентичан члан се налази и у Уставу Краљевине Југославије из 1931. године: „Службени језик Краљевине је српско-хрватско-словеначки" (Српски устави 2004: 227).
} 
ри „истојезичне републике”, данас самосталне државе, и оне су имале исти језички израз, израђен на моделу реформе Вука Стефановића Караџића. Територија прве Југославије није се мењала до Другог светског рата, мада је 1939. године било административних промена унутар саме државе, пре свега реорганизовањем бановина.

Стварање нове државе после Првог светског рата у новим друштвеноисторијским околностима није се одразило на српски језик и његову норму, посебно не на правописну норму, ни у Србији ни изван ње, тј. на простор каснијих „истојезичних република”. Како је до тога дошло, данас није тешко одговорити. Хрватска, Босна и Херцеговина и Црна Гора прихватиле су Вукову језичку и правописну реформу и пре стварања прве Југославије, па нови друштвеноисторијски аспект није посебно утицао на језик и правопис. Ово изгледа помало необично, сличних процеса није много забележено у целом свету.

Заправо, српски језик и његов правопис од појаве Српског рјечника, 1818. године, преко стварања прве Југославије па све до данас, пуна два века, имали су јасан континуитет, све што се дешавало имало је еволутиван ток, није било радикалних и великих промена када је посреди норма. Сасвим је логично да су се нека решења мењала, очекивано је и да је било допуна и објашњења, али у та два века није било (пре)великих захвата и преправки норме. У књизи Српски језик на крају века, говорећи о нашој правописној норми, Митар Пешикан (1996: 171) с правом закључује да од Вукове реформе није било озбиљних „правописних преокрета”, већ да су правописне измене имале „карактер дораде, разраде и трагања за решењима која ће бити у што бољем складу с природом књижевног језика". ${ }^{2}$ Следећи цитат јасно објашњава стање на прелазу XIX у XX век: „Крајем XIX века Вукова реформа и вуковски језик, граматика и правописни основи прихваћени су и у хрватској језичкој култури, а тиме се проширило и поље и домашај примене оног књижевног језика који је Вук утемељио као српски језик, и по имену и по основном карактеру. Хрватским прихватањем тога језика он је постао употребно српскохрватски. Иако на његовом простору процес етничке и националне идентификације, диференцирања и разграничавања још није био довршен и коначан, објективно се српски књижевнојезички израз опет нашао у наднационалној нормативној заједници, овога пута стогодишњег трајања" (Пешикан 1996: 171).

У српској правописној литератури још увек немамо целовит приказ историје правописа, немамо ни хрестоматије важних докумената и одлука, и то сматрамо великим недостатком. Појединачних радова има, поједини догађаји и документи су анализирани, али свеобухватног систематског текста још увек

\footnotetext{
${ }^{2}$ Књига Српски језик на крају века настала је као резултат рада на пројекту који је 1992 . године иницирао професор Станислав Гајда (Институт за пољску филологију, Универзитет у Ополу). Пројекат је носио службени назив Савремене промене у словенским језицима (1945-1995), рађен је под окриљем Пољске академије наука и Међународног комитета слависта. Координатор потпројекта за српски језик и редактор књиге био је професор Милорад Радовановић.
} 
нема. ${ }^{3}$ Због тога се и у стручној литератури повремено сусрећу непоуздане тврдње и не баш најпрецизнија тумачења. У нашем окружењу је било таквих покушаја, тако је код Хрвата Марко Самарџија објавио две обимне књиге, са више од 1000 страна докумената и њихових тумачења: Hrvatski jezik $i$ pravopis od ujedinjenja do kraja Banovine Hrvatske (1918.-1941.) и Hrvatski jezik, pravopis i jezička politika u NDH. Сличан покушај налазимо и у Сарајеву, где је Милан Шипка објавио збирку докумената Standardni jezik i nacionalni odnosi u Bosni i Hercegovini (1850-2000) - Dokumenti. ${ }^{4}$ Истина, књига Милана Шипке не садржи коментаре, већ само оригинална документа, тј. њихове копије, на око 350 страна.

\section{2. Правопис пре Првог светског рата}

У Србији је Вукова језичка и правописна реформа званично прихваћена 1868. године, српски правопис је неспорно Вуков и вуковски у правом смислу тих речи, али тада још увек није било целовитог правописног приручника. До настанка прве Југославије (1918. године) Срби су добили неколико правописних приручника и правописних елаборација различитог квалитета и квантитета. Заједнички именитељ им је да подржавају Вукова решења, да их снаже, описују и тиме учвршћују оно што је Вук најавио пола века пре коначне победе, у знаменитом Српском рјечнику. Вукова реформа у Србији је оснажена у Српској граматици Стојана Новаковића (1894), где је правопис систематски изложен, а појављују се и нови правописни приручници: Cpncки правопис за школску употребу Стеве Чутурила (1884) и Српски правопис за средње школе Милана Петровића (1914). Тиме је Вукова правописна реформа доживела и кодификацију.

Хрвати су и званично прихватили Вуков језички и правописни модел у последњој деценији XIX века, практично више од две деценије пре стварања заједничке државе. Колико је ту било утицаја друштвеноисторијских прилика и колико случајности, то је сада тешко доказати. Није спорна претпоставка да би језичко уједињење на некој другој основи за Хрвате било и теже и неизвесније и, нама се чини, неповољније за процесе који ће уследити. Прихватање Вуковог језичког модела, на неки начин је резултат илирског покрета, књижевног договора у Бечу, одласка Ђуре Даничића у Загреб, али и читавог сплета других околности. ${ }^{5}$

\footnotetext{
${ }^{3} \mathrm{O}$ појединим догађајима из историје српске ортографије може се наћи доста података у књигама: Правопис српског језика у наставној пракси (Брборић 2004), Правопис и школа (Брборић 2015), О српском правопису (Брборић 2016а), Муке око језика и правописа (Брборић 2019).

4 Заправо, у литератури се често налазе устаљене тврдње о појединим периодима и догађајима, често се „бежало” од оригиналних докумената и њихових стварних одлука. Некада је то чињено због „братства и јединства” и крхког заједништва, али и због укупних друштвеноисторијских околности. Стога сматрамо да је од велике важности окупити на једном месту све доступне одлуке и објавити их, с кратким коментарима.

${ }^{5}$ Илирски покрет је у првом реду био књижевни и друштвенополитички покрет, развио се међу јужним Словенима Аустријског царства у трећој и четвртој деценији XIX века. Главни
} 
Директна и јасна потврда прихватања српског језика у Хрватској јесте објављивање значајних филолошких дела крајем XIX века. Прво је објављен Хрватски правопис Ивана Броза (1892), потом Граматика и стилистика хрватскога или српскога језика Томислава Маретића (1899) и Броз-Ивековићев Рјечник хрватскога језика (1901). После појаве ових приручника прихватање Вуковог језичког модела није могло бити спорно, мада су повремена оспоравања и неспоразуми обележили скоро читав XX век, све до политичког осамостаљења Хрватске и дефинитивног озваничења засебног („хрватског”) језика.

Но, да се сада вратимо само правопису. Кључна година када је у Хрватској прихваћен Вуков (српски) правопис је 1892, тада је „по одређењу кр. зем. владе, одјела за богоштовље и наставу" штампан Хрватски правопис Ивана Броза. ${ }^{6}$ У опширном предговору, на седам страна, аутор објашњава шта је задатак правописа и како је настао овај приручник. Једна реченица из предговора јасно показује опредељење аутора: „Ја sam izradio pravila u glavnome prema načelima, kojih se držao Vuk i Daničić, a samo gdješto odstupio sam od njihova pisanja" (Броз 1892: III). ${ }^{7}$ На основу предговора и цитиране реченице и текста књиге можемо закључити да друштвеноисторијске прилике нису утицале да Хрвати четврт века пре стварања заједничке државе у целини прихвате српски правопис и његова правописна начела, она која је Вук Караџић инаугурисао још 1818. године.

Драгољуб Петровић тврди у Школи немуштог језика да је одлучујућу улогу у прихватању Вукових решења у Хрватској одиграо Ђуро Даничић првим томом Рјечника хрватскога или српскога језика (1880) и да су тај посао довршили хрватски вуковци - правописом, граматиком и речником (Броз, Маретић и Ивековић), од којих се „пише модерна историја ‘хрватског језика'” (Петровић 1996: 304). Нама изгледа да су Хрвати, сплетом срећних околности и избором Вуковог језичког и правописног модела, у ХХ веку водили рачуна само о личном интересу. Наиме, тако су језички ујединили све територије за које су били „заинтересовани” и у тадашњој матичној држави и изван ње. То би на неком другом језичком идиому било неупоредиво теже, заправо немогуће остварити.

циљ покрета било је политичко и језичко јединство свих Јужних Словена, тј. „Илира”. Покрет је трајао од 1830. до 1850, званично је био забрањен 1843. године. Једна од идеја је била потпуно јединство српског и хрватског језика и правописа. Бечки књижевни договор није био званичан скуп, али су његове идеје ,провејавале” од средине XIX до краја XX века. Одлазак Ђуре Даничића у Загреб имао је далекосежне последице, он је још 1866. отишао тамо за секретара тек основане Југословенске академије, а посебно је значајан његов рад на припреми Рјечника хрватскога или српскога језика.

${ }^{6}$ Павле Ивић каже да је тада у Загребу крилатица „пиши као што говориш” више имала значење „пиши као Вук”, безрезервно угледање на Вука било је јасно и у граматици и у правопису - код Маретића и Броза (Ивић 1998: 12).

${ }^{7}$ Ову изјаву И. Броза потврдио је и велики хрватски лингвиста Далибор Брозовић, скоро век касније: „Brozov pravopis unosi u hrvatsku jezičku praksu fonološka ortografska načela, otprilike ona ista koja je u Srba inaugurisao Karadžić godine 1818. svojim velikim Srpskim rječnikom" (Brozović 1983: 252). 
У Босни и Херцеговини је још раније прихваћен српски (Вуков) правописни модел. ${ }^{8}$ Наиме, на такав, неспорни закључак упућује увид у докуменат Ревизија правописа српско-хрватскога језика - Свим одељењима земаљске владе, затим свим областима, уредима, судовима, заводима и школама у земљи. На самом почетку тога документа се каже: „Za pismeno upotrebljavanje srpsko-hrvatskoga jezika uveden je 1883. godine u ovozemne javne urede i škole t.zv. Vuk-Daničićev fonetski pravopis" (Revizija 1912: 1). ${ }^{9}$ О засебном језику у Босни и Херцеговини тада није било речи, мада је било повремених колебања око његовог имена, тј. назива језика.

У Црној Гори у XIX и XX веку назив језика и правописна решења нису били спорни. Први пут се о језичкој и правописној „посебности” проговорило тек крајем XX века, пре „растакања” политичке заједнице „истојезичних република". Потпуно оправдано можемо рећи да је Црна Гора језички и правописно у XX веку живела са атрибутом српски и да је у свему подржавала језичку политику коју су водили српски лингвисти, без било каквих покушаја и приче о некаквој црногорској посебности.

Све то нам даје за право да поновимо да је крајем XIX века Вуков језички и правописни модел прихваћен у Хрватској, Босни и Херцеговини и Црној Гори, после озваничења у Србији (1868), а пре стварања заједничке државе (1918). У Црној Гори је био у употреби искључиво термин српски и за језик и за правопис, док је у Босни и Херцеговини коришћен термин српско-хрватски (са цртицом), а у Хрватској термин хрватски језик (али и термин хрватски или српски језик) и правопис. Тако је, без посебног ангажовања било кога из Србије, српски правопис прихваћен изван Србије, само што назив није био потпуно идентичан. Језичко и правописно уједињење претходило је политичком. Друштвеноисторијске прилике и правописна питања нису били у узрочно-последичној вези, неупоредиво је чешћи обрнут процес.

\section{3. Правопис после Првог светског рата}

Године 1918. наступају нове друштвеноисторијске околности, ствара се нова држава, с новим називом језика, али се ништа не мења у језичкој и правописној норми и његовој вуковској основи. Тек касније ће се видети да

\footnotetext{
${ }^{8}$ Уредбом земаљске владе у Сарајеву из 1879 . године и основањем Реалне гимназије међу предметима који се уче сусрећемо назив земаљски језик, али се у загради налази одређење (хрватски, српски) (Šipka 2001: 75). Истина, у неким документима се може наћи и термин босански земаљски језик. На почетку XX века у тексту Закона о уређивању званичног и наставног језика у Босни и Хериеговини (1913) сусрећемо и ову одредницу: „Srpsko-hrvatski jezik je zvanični jezik u svim bosansko-hercegovačkim vlastima, uredima i zemaljskim zavodima za sve poslove građanske uprave na upravnom području Bosne i Hercegovine, u unutrašnjom i spoljašnjem saobraćaju. Isto vrijedi o nastavnom i zvaničnom jeziku svih nastavnih građanskih zavoda” (Šipka 2001: 110).

${ }^{9}$ Ревизија је донета 1912. године и она неспорно потврђује правописно уређење у Босни и Херцеговини од 1883. до 1912. године. Текст ревизије има 30. чланова, она само учвршћује и прецизира Вукова правописна начела. Први члан ревизије гласи: „Za obadva pisma, kojima se bilježi srpsko-hrvatski govor, vrijedi isti pravopis”. На крају Ревизије налази се и напомена: „Za ostalo mogu kao vođ u srpsko-hrvatskoj ortografiji poslužiti pravila već gore pomenute Broz-Boranićeve knjige" (Revizija 1912: 1-6).
} 
је прва југословенска држава била оптерећена бројним проблемима, било је доста неразумевања, честих и тешких неспоразума и несугласица, понајвише између Срба и Хрвата, а то се одразило и на језичку и културну политику. Политичке неспоразуме пратиле су и језичке несугласице.

Доста је заблуда о језичком и културном јединству у новој држави. Хрвати су константно истицали да се њихова „самобитност” утапа у југословенство и да на тај начин остају без језичког и културног идентитета, а прича о наметању из Београда и њиховој наводној „националној угрожености” није престала. Чини се да су Хрвати јасно и организовано, поприлично свесно и истрајно, увек указивали како у новој друштвеној заједници нема довољно хрватске „самобитности”. Термин угроженост био је обавезујући за све хрватске политичке и културне представнике, нарочито после атентата на краља Александра (1934. године). То се, врло директно, видело и у приступу језичкој и правописној стварности, које лепо илуструју две често понављане тврдње Марка Самарџије, актуелне и на почетку XXI века: 1. „A hrvatske novine iz prvih godina nove države ('Obzor', 'Hrvat') učestalo donose vijesti o tome kako se u hrvatskim krajevima razmahao proces nazvan ćirilizacija ili ćiriliziranje (ironično i ćirilizovanje), tj. prodiranje srpske ćirilice u krajeve u kojima je to pismo dotada bilo nepoznato. Taj je proces, dakako, počesto poprimao oblik otvorena nametanja ćirilice i potiskovanje latinice. Upravo se zbog toga kadšto, makar i s vremenskom zadrškom, moralo otvoreno reagirati, npr. 'Kad Srbin govori o ravnopravnosti latinice i ćirilice, onda to znači, da Srbi ne smiju pisati latinicom, a Hrvati moraju pisati ćirilicom”” (Samardžija 2008: 16) и 2. „Kad je nakon balkanskih ratova (1912.-1913.) učvršćen mit o Srbiji kao južnoslavenskom Piemontu, iz tog će mita izrasti i unitarna jezična nastojanja prvi put izrijekom iznesena u poznatom javnom predavanju 'Istočno ili južno narečje?' (održano u Beogradu 4. studenoga 1913.) srpskoga sveučilišnog profesora i političara Jovana Skerlića (1877.-1914.) 'apostola modernog jugoslovenskog nacionalizma"” (Samardžija 2012: 15). Самарџија овде понавља тезу која говори о наметању језика и писма из Београда, позива се на 1913. (Скерлићева Анкета) и 1918. годину (стварање заједничке државе), и при том заборавља и прећуткује да су Хрвати прихватили Вуков (српски) језички модел још у последњој деценији XIX века, двадесет година пре оних на које се позива Самарџија. То је, нема сумње, селективан и тенденциозан приступ проблему и он не показује истину јер чињенице говоре другачије. По томе колико је било „наметање” ћирилице најбоље сведочи читав ток XX века и резултат на крају века. Ћирилице у Хрватској нема, а латиница је доминантнија и у Србији, и то је резултат „наметања” из Београда. Што се Скерлићевог предавања и Анкете тиче, и ту чињенице говоре супротно. Она се тицала, у првом реду, само књижевног изговора. И Анкета је била пре Првог светског рата, а рат ју је учинио неактуелном. Одговоре су послала 32 анкетирана аутора, а мора се водити рачуна о актуелном тренутку (1913. година). Данашњи поглед на тадашњу ситуацију свакако је промењен, па и закључак може бити другачији. Већина учесника, њих 21, изјаснила се за прихватање екавског изговора. Импресиван је податак да су сви Срби из западних крајева, изворни ијекавци, били 
одлучно за екавицу, што сведочи о њиховом патриотизму (Алекса Шантић, Светозар Ћоровић, Владимир Ћоровић, Ђорђе Пејановић, Милан Марјановић, Васо Глушац, Вељко Милићевић). ${ }^{10}$ Чињеница је да су за екавицу била оба анкетирана Словенца (Фран Илешић и Иван Хрибар). Далматинци Јосип Смодлака и Владимир Черина и Истранин Милан Марјановић такође су били да се прихвати екавица, док су Дубровчани Милан Решетар и Иво Војновић сматрали да не треба ништа мењати. Такав је био и одговор Томислава Маретића, Петра Скока, као и двојице хрватских писаца, Рикарда КаталинићаЈеретова и Рикарда Николића. ${ }^{11}$

Најзначајнији допринос учвршћивању правописне норме после Првог светског рада свакако је штампање Правописа срискохрватског књижевног језика Александра Белића. Истина, Хрвати су и даље задржали Боранићев (Броз-Боранићев) правопис, који је поштовао дух Вукове реформе. ${ }^{12}$ Белић је био лингвиста с огромним ауторитетом, великом репутацијом и великим утицајем у Србији и у окружењу. У предговору Правописа каже: „Свако зна да у писању речи влада у нашем језику прилична неједнакост. Задатак је ове књиге да ту неједнакост, у колико је могуће, уклони” (Белић 1923: 1). Када се појавио Белићев Правопис српскохрватског књижевног језика, он је одмах био прихваћен као обавезујући приручник код Срба, био је прихваћен и у Црној Гори и у Босни и Херцеговини, док је код Хрвата остао у употреби Боранићев приручник. Врло брзо ће се показати да је то увод у нове неспоразуме. О чему се заправо радило? Александар Белић је био „радикалан вуковац, упорно одан Вуковим принципима", а с друге стране био је Боранићев правопис „истрајно веран Вуку у конкретним решењима” (Ивић 1968/69: 27). Иако обе вуковске концепције, једна је доживљена као српска, а друга као хрватска. Правопис хрватскога или српскога језика Драгутина Боранића из 1921. године незнатно је поправљен у односу на изворни Ивана Броза из 1892. године. Између њега и Белићевог Правописа било је врло мало разлика, па се размишљало о њиховом уједначавању. По тумачењима из Хрватске, А. Белић је још 1926. године добио задатак од просветних власти да припреми основу за „договорни правопис”, а потом је 1927. министар просвете Ми-

${ }^{10}$ Да се Анкета бавила питањима, пре свега, заједничког изговора, најбоље ће послужити сведочење самог Марка Самарџије: „Ро vlastitim podatcima skupljenima s tim u vezi kao i po panorami tadanjega hrvatskog pjesništva (izostavivši danas manje poznate i zaboravljene autore) vidi se da je prilično dug popis tada uglavnom mladih hrvatskih književnika koji su kraće ili duže vrijeme svoja djela (pretežno pjesme, ali ima i nešto proznih radova i prijevoda) pisali ekavicom: Ivo Andrić, Frano Alfirević, Antun Barac, Niko Barlutović, August Cesarec, Dobriša Cesarić, Ante Cettineo, Vladimir Čerina, Ulderiko Donadini, Miroslav Feldmar, Josip Kosor, Vladimir Kovačević, Gustav Krklec, Miroslav Krleža, Josip Kulundžić, Jakša Kušan, Vjekoslav (Vjeko) Majer, Milan Marijanović, Dragan Micić, Ljubomir Micić, Marijan Mikas, Sibe Miličić, Zvonko Milković, Alija Nametak, Luka Perković, Đuro Sudeta, Antun Branko Šimić, Stanislav Šimić, AugusTin Ujević” (Samardžija 2012: 18-19).

${ }^{11}$ Што се тиче Скерлићеве Анкете, сви одговори и њихова тумачења могу се наћи у књизи $O$ Анкети Јована Скерлића у Српском књижевном гласнику (Брборић 2016б).

${ }^{12}$ Хрватски правопис Ивана Броза из 1892. године излази од 1904. као Броз-Боранићев Правопис, а од 1921. године само са Боранићевим именом и називом Правопис хрватскога или српскога језика. У издању из 1930. опет је назив језика гласио хрватски или српски, а у издањима из 1934. и 1937. језик је именован као хрватскосрпски. 
лош Трифуновић основао посебан одбор са задатком да уједначи Белићев и Боранићев правопис. У том одбору су били афирмисани и познати језички стручњаци: Александар Белић, Љубомир Стојановић, Стјепан Куљбакин, Фран Рамовш, Томо Маретић, Милан Решетар (касније га је заменио Стјепан Ившић) и Драгутин Боранић. Тако је урађена мања правописна реформа у форми Правописног упутства (Самарџија 2008: 19). ${ }^{13}$ Састав овог одбора је за свако поштовање, реч је о најистакнутијим језичким стручњацима тога периода, што сведочи о озбиљним намерама државе.

\section{4. Правописно упутство из 1929. године}

Пуни назив обавезујућег правописног документа био је Правописно упутство за све основне, средње и стручне школе Краљевине С. Х. С. Заправо, власт је овде искористила школски систем да се преко њега направе обавезујуће правописне препоруке и да оне важе на целој територији на којој се говори српскохрватски језик, како у систему школства тако и изван њега. Заправо, школски систем овде је био само изговор за уједначавање ситних неуједначености у два правописна приручника. Тако се у предговору каже: „У свим се школама наше земље употребљава један правопис, заснован на великој језичкој и правописној реформи Вука Караџића. Али и поред тога што се тај правопис држи истих основних принципа, ипак су се у различитим крајевима наше земље развиле неједнакости у њему које спречавају да се настава у њима потпуно уједначи. С друге стране, често и сами наставници не знају који је правописни начин бољи и који треба употребљавати” (Правописно упутство 1929: 3).

Колико је Правописно упутство било обавезујуће и каква је намера државе била, најбоље сведочи следећа реченица из предговора: „Начин писања изнесен у овом правилнику мора се примењивати у свим новим издањима школских књига. Ниједан уџбеник, било да представља ново издање раније издате књиге, било да се сада први пут издаје, не може бити одобрен за школску књигу, ако није израђен по овим правилима" (Правописно упутство 1929: 3-4).

Вреди поновити да су у изради Правописног упутства учествовали аутори постојећих приручника (Белић и Боранић). Ипак, и после Правописног упутства немамо један правопис, а већ 1930. године имамо нова издања и Белићевог и Боранићевог приручника, са напоменом да су урађена у складу са Правописним упутством. Ново издања Белићевог Правописа (друго, прерађено издање) доноси као назив језика „српскохрватски”, док то код Боранића није случај, па у издању из 1930. на корицама стоји Правопис хрватскога или српскога језика (прерађено према прописима Министарства просвете).

\footnotetext{
${ }^{13}$ Правописно упутство је објављено у Просветном гласнику, потом је, до краја године, доживело неколико издања у облику засебне брошуре, чак три издања у Хрватској (два у Загребу и једно у Дубровнику). Издања у Хрватској штампана су латиницом, а у Србији ћирилицом.
} 
То може сведочити о искреним намерама са хрватске стране, али и тврдња Павла Ивића сигурно није без основа: „И кад је ускоро затим нови званични компромисни правопис усвојио велики део Белићевих иновација, то је доживљено као наметање Београда" (Ивић 1968/69: 27).

Правописно упутство је имало 40 страна, настојало је да уједначи мања и повремена колебања, али му је основни циљ био да сведочи о правописном јединству и правописној концепцији и целовитости. То најбоље показују и његова засебна поглавља, њих 17 (и 155 тачака правописних правила): I Азбука; II Писање великих и малих слова; III Подела речи на слогове; IV Одвојено и састављено писање речи; V O самогласницима; VI Књижевни изговори; VII Писање гласа ,j”; VIII Писање „ћ” и „ч”, „ћ” и „џ”; IX Писање гласа „X”; X О групама самогласника; XI Удвајање сугласника; XII Једначење сугласника по звучности; XIII Групе различитих сугласника; XIV Губљење сугласника; XV Интерпункција; XVI Други знаци; XVII Транскрипција туђих речи и имена (Правописно упутство 1929: 1-40).

Тако смо 1930. године имали два правописна приручника, али су њихова правописна решења била идентична и тиме је и формално постигнуто потпуно правописно јединство на подручју каснијих „истојезичних република”, за све оне који су језик називали српскохрватски (хрватски или српски). Било је то на стогодишњицу илирског покрета, можда је у томе било и симболике. Хрвати су у јавним иступима сведочили о наметнутим променама из Београда, а Боранић је у четвртој деценији XX века имао три издања правописа, усклађена са Упутством (1930, 1934. и 1937. године), Белић два (1930. и 1934).

Просветне власти су настојале да додатно јачају језичко јединство, тако су објављене књиге Средњошколска терминологија и номенклатура и Граматичка терминологија, обе 1932. године (Самарџија 2012: 152). Атентат у Марсеју (1934), споразум Драгише Цветковића и Влатка Мачека (1935), али и оснивање Друштва за хрватски језик (1936) и издавање часописа Хрватски језик (1938), уз потенцирање разлика између српског и хрватског језика, све то као да је припремало терен за поновно језичко раздвајање. Тиме се рушила хрватска правописна традиција од пола века, двадесетогодишње политичко јединство и већ прихваћене језичке и правописне навике.

Политичка, тј. друштвеноисторијска превирања у Краљеви Југославији донела су 1939. године нову административну организацију земље. Тако се оснивањем Бановине Хрватске у Хрватској враћа „стара” Боранићева правописна норма, она пре 1929. и Правописног упутства, и тиме је тешко постигнуто заједништво, на неки начин, напуштено. Правописно заједништво је трајало само десет година. ${ }^{14}$ Све то као да је најављивало нове друштвеноисторијске и језичке неспоразуме. Стварањем Независне Државе Хрватс-

\footnotetext{
${ }^{14}$ По Уставу Краљевине Југославије држава је имала девет бановина: 1. Дравска са седиштем у Љубљани, 2. Савска са седиштем у Загребу, 3. Врбаска са седиштем у Бања Луци, 4. Приморска са седиштем у Сплиту, 5. Дринска са седиштем у Сарајеву, 6, Зетска са седиштем на Цетињу, 7. Дунавска са седиштем у Новом Саду, 8. Моравска са седиштем у Нишу, 9. Вардарска са седиштем у Скопљу (Српски устави 2004: 242).
} 
ке и доласком усташке власти, Хрвати брзо раскидају језичко и правописно заједништво. Врло брзо је уследила одлучна акција тоталитарног режима у Загребу, донете су Законска одредба о забрани ћирилице, Законска одредба о оснивағу Хрватског државног уреда за језик, министарска наредба Охрватском правопису и законска одредба о хрватском језику, о његовој чистоћи и правопису, а све то се десило 1941. године. Заправо, забрањен је било какав правопис осим кориенскога и брзо се појавило Кориенско писање Братољуба Клаића (1942), чиме је суспендовано правописно заједништво. Прелазак на нови начин писања постао је обавезујући у Независној Држави Хрватској.

Како је изгледала језичка политика у новим друштвеноисторијским околностима, најбоље сведоче речи Законска одредба о хрватском језику, његовој чистоти и о правопису. У тој одредби се, између осталог, каже: „Jezik, što ga govore Hrvati, jest po svom izvoru, po povijesnom razvitku, po svojoj rasprostranjenosti na hrvatskom narodnom području, po načinu izgovora, po slovničkim pravilima i po značenju pojedinih rieči izvorni i osebujni jezik hrvatskog naroda, te nije istovjetan ni s jednim drugim jezikom, niti je narječje bilo kojeg drugog jezika, ili bilo s kojim narodom zajedničkog jezika. Zato se zove 'hrvatski jezik'” (Koriensko pisanje 1942: 16-17).

Када су Хрвати напустили језичко и правописно заједништво, с извесним кашњењем, уследила је реакција и српске стране. Тако је 1942, у време Недићеве владе, урађено Ново правописно упутство и оно је постало обавезујуће од 1. јануара 1943. године. Ово је, заправо, повратак на изворни Правопис А. Белића, из 1923. године. Објашњења у предговору не делују убедљиво: „Правописна упутства која је прописало Министарство просвете 1929. године, и поред стручне комисије која је на њима радила, и поред званичног наређења, и поред тринаестогодишње употребе, нису успела да се учврсте" (Ново упутство 1943: 3). ${ }^{15}$

Када се у обзир узму све познате чињенице из назначеног периода, тешко се може рећи колико је политичко јединство прве Југославије било искрено, у првом реду са хрватске стране. То се директно одразило и на заједнички језик и правопис. Можда је добро послушати мишљење америчког лингвиста Кенета Нејлора: „Različite kulturne i književne tradicije koje su postojale pre 1918. godine nastavile su da postoje i posle stvaranja nove države. Pređašnje postojanje Jugoslovenske akademije znanosti i umjetnosti u Zagrebu, i Srpske kraljevske akademije u Beogradu, kao i univerziteta u Zagrebu i Beogradu, nisu umanjili jezičko rivalstvo. U međuratnom periodu odvijale su se žive filološke debate povodom književnog jezika na obe strane. Aleksandar Belić je sugerisao da se izvesno sjedinjavanje ove dve neznatno različite verzije književnog jezika dogodilo dvadesetih godina ovog veka. Tokom Drugog svetskog rata, ustaše su se koristile starim sukobima, [...] koji su upravo stavljali naglasak na razlike između ‘srpskoga` i 'hrvatskoga'” (Nejlor 1996: 106-107).

\footnotetext{
${ }^{15}$ Ово објашњење не делује јасно. Ако се Белићев Правопис из 1930. до 1942. није учврстио (12 година), како ће се онда учврстити онај који је био у употреби од 1923. до 1929. (шест година), а разлике нису биле велике.
} 
Уследио је Други светски рат, током кога су се језик и правопис у новим друштвеноисторијским условима одвојили, али је после рата поново враћено језичко и правописно заједништво. После Другог светског рата имамо нова издања „усклађених” правописних приручника А. Белића и Д. Боранића. Они су „сачекали” Новосадски књижевни договор из 1954. године и заједнички Правопис српскохрватскога књижевног језика из 1960. године.

\section{5. Закључак}

Правопис којим се данас служимо резултат је правописне реформе Вука Караџића, оне која је изнета у Српском рјечнику. Тај правопис, који је званично прихваћен 1868. и потом додатно објашњен и ојачан, кодификацију је доживео крајем XIX века.

Вукови правописни принципи прихваћени су и изван Србије крајем XIX века, пре стварања прве Југославије. У Хрватској су „хрватски вуковци” тај посао решили објављивањем најзначајнијих кодификаторских књига (граматика, правопис, речник).

Босна и Херцеговина и Црна Гора прихватају Вукова правописна решења и тамо није било речи о језичкој и правописној посебности и пре стварања прве Југославије.

Стварањем прве Југославије имали смо два правописна приручника, Белићев и Боранићев, с малим неуједначеностима. Правописним упутством из 1929. године правописна решења су уједначена и тако је 1930. године направљено и озваничено правописно јединство, с два правописна приручника. Заједништво је трајало само до стварања Бановине Хрватске 1939. године и поново су се Хрвати језички и правописно удаљили од Срба.

У међуратном периоду у неким случајевима друштвеноисторијске прилике нису утицале на правописну норму, док је у неким случајевима норма директно зависила од нових околности.

Друштвеноисторијске прилике нису утицале на правописна решења нашег језика пре стварања прве Југославије, али су у међуратном периоду били очигледни такви утицаји, и то неколико пута са хрватске стране. Ово изгледа помало парадоксално, језичко и правописно јединство је постигнуто док није било заједничке државе, али га је било тешко одржати у заједничкој држави.

\section{ЛИТЕРАТУРА}

Белић ${ }^{1}$ 1923 [ ${ }^{2}$ 1930, ${ }^{3}$ 1934, ${ }^{4}$ 1950]: А. Белић, Правопис српскохрватског књижевног језика, Београд: Издавачка књижарница Геце Кона.

Boranić ${ }^{2}$ 1923: D. Boranić, Pravopis hrvatskoga ili srpskoga jezika, Zagreb: Naklada Ćirilo-Metodske nakladne knjižare.

Broz 1892: I. Broz, Hrvatski pravopis, Zagreb. 
Brozović 1983: D. Brozović, „Jezička i pravopisna previranja u Hrvatskoj na prijelazu iz 19. u 20. stoljeće", u: Jezici i književnosti naroda Jugoslavije na prijelazu iz 19. u 20. stoljeće, Zadar: 34. Jugoslavenski seminar za strane slaviste, 243-258.

Брборић 2004: В. Брборић, Правопис српског језика у наставној пракси, Београд: Филолошки факултет.

Брборић 2015: В. Брборић, Правопис и школа, Београд: Друштво за српски језик и књижевност Србије.

Брборић 2016а: В. Брборић, О српском правопису, Београд: Друштво за српски језик и књижевност Србије.

Брборић 2016б: В. Брборић, О Анкети Јована Скерлића у Српском књижевном гласнику, Београд: Чигоја штампа.

Брборић 2019: В. Брборић, Муке око језика и правописа, Нови Сад: Прометеј.

Ивић 1996: П. Ивић, „О Вуковом рјечнику из 1818. године” (поговор) у: $C p$ пски рјечник, Београд: Просвета.

Ивић 1998: П. Ивић, „Из прошлости српског правописа”, у: К новој писмености, Београд: Научна књига, 11-15.

Nejlor 1996: K. Nejlor, Sociolingvistički problemi među Južnim Slovenima, Beograd: Prosveta.

Новаковић 1894: С. Новаковић, Српска граматика, Београд: Државна штампарија.

Ново упутство 1943: Ново правописно упутство српског књижевног језика, Београд: Издавачко и прометно А. Д. Југоисток.

Петровић М. 1914: М. Петровић, Српски правопис за средюе школе, Нови Сад: Штампарија „Натошевић”.

Петровић Д. 1996: Д. Петровић, Школа немуштог језика, Нови Сад: Цветник.

Пешикан 1996: М. Пешикан, „Правописна норма”, у: Српски језик на крају века, Београд: Институт за српски језик САНУ_Службени гласник, 171-179.

Правопис 1960: Правопис српскохрватскога књижевног језика са правописним речником (израдила правописна комисија), Нови Сад - Загреб: Матица српска - Матица хрватска.

Правописно упутство 1929: Правописно упутство за све основне, средње и стручне школе, Београд: Државна штампарија Краљевине Југославије.

Revizija 1912: Revizija pravopisa srpsko-hrvatskoga jezika, Sarajevo.

Samardžija 2008: M. Samardžija, Hrvatski jezik, pravopis i jezička politika u Nezavisnoj Državi Hrvatskoj, Zagreb: Hrvatska sveučilišna naklada.

Samardžija 2012: M. Samardžija, Hrvatski jezik i pravopis od ujedinjeneja do kraja Banovine Hrvatske (1918.-1941.), Zagreb: Školska knjiga.

Српски устави 2004: Српски устави од 1935. до 1990. године са Уставима Краљьевине СХС и Краљевине Југославије, Београд: Граматик.

Чутурило 1884: С. Чутурило, Српски правопис за школску употребу, Панчево: Књижара браће Јовановић.

Šipka 2001: M. Šipka, Standardni jezici i nacionalni odnosi u Bosni i Hercegovini (1850-2000) - Dokumenti, Sarajevo: Institut za jezik u Sarajevu (posebna izdanja - knjiga 11). 
Veljko Ž. Brborić

\section{SOCIOHISTORICAL ASPECTS OF SERBIAN ORTHOGRAPHY BETWEEN THE TWO WORLD WARS}

\section{Summary}

The paper deals with the orthography of our language (Serbian/Serbo-Croatian) between the two world wars on the territory of the former ,same-language republics”, today independent states: Serbia, Croatia, Bosnia and Herzegovina and Montenegro. In fact, it is about the acceptance of Vuk Karadžić's (Serbian) orthography and its rules before the creation of the first Yugoslavia and the influence of socio-historical circumstances on orthography in the period between the two world wars. 